Review

\title{
Function of Platelet Glycosphingolipid Microdomains/Lipid Rafts
}

\author{
Keisuke Komatsuya ${ }^{\circledR}$, Kei Kaneko and Kohji Kasahara *®D \\ Laboratory of Biomembrane, Tokyo Metropolitan Institute of Medical Science, Tokyo 156-8506, Japan; \\ komatsuya-ks@igakuken.or.jp (K.K.); ikekoneka@isc.chubu.ac.jp (K.K.) \\ * Correspondence: kasahara-kj@igakuken.or.jp
}

Received: 29 June 2020; Accepted: 30 July 2020; Published: 2 August 2020

\begin{abstract}
Lipid rafts are dynamic assemblies of glycosphingolipids, sphingomyelin, cholesterol, and specific proteins which are stabilized into platforms involved in the regulation of vital cellular processes. The rafts at the cell surface play important functions in signal transduction. Recent reports have demonstrated that lipid rafts are spatially and compositionally heterogeneous in the single-cell membrane. In this review, we summarize our recent data on living platelets using two specific probes of raft components: lysenin as a probe of sphingomyelin-rich rafts and $\mathrm{BC} \theta$ as a probe of cholesterol-rich rafts. Sphingomyelin-rich rafts that are spatially and functionally distinct from the cholesterol-rich rafts were found at spreading platelets. Fibrin is translocated to sphingomyelin-rich rafts and platelet sphingomyelin-rich rafts act as platforms where extracellular fibrin and intracellular actomyosin join to promote clot retraction. On the other hand, the collagen receptor glycoprotein VI is known to be translocated to cholesterol-rich rafts during platelet adhesion to collagen. Furthermore, the functional roles of platelet glycosphingolipids and platelet raft-binding proteins including $\mathrm{G}$ protein-coupled receptors, stomatin, prohibitin, flotillin, and $\mathrm{HflK} / \mathrm{C}$-domain protein family, tetraspanin family, and calcium channels are discussed.
\end{abstract}

Keywords: lipid rafts; detergent-resistant membrane; heterogeneity; platelets; lysenin

\section{Platelet Lipid Rafts}

The fluid mosaic model has supported our understanding of cellular membranes for a long time. Recent studies suggest that plasma membrane lipids are not homogeneously distributed and that the membranes may contain microdomains or compartments. Glycosphingolipids form microdomains containing cholesterol in the cell membrane. Glycosphingolipid- and cholesterol-rich microdomains are referred to as lipid rafts. Lipid rafts are dynamic assemblies of glycosphingolipids, sphingomyelin, cholesterol, and proteins which are stabilized into platforms involved in the regulation of a number of cellular processes [1]. Lipid rafts are isolated as a detergent-resistant membrane (DRM) fraction by sucrose density gradient centrifugation. Recent studies have demonstrated that lipid rafts are spatially and compositionally heterogeneous in the cell membrane. In migrating T cells, GM3 ganglioside-rich rafts containing a chemokine receptor are present at their leading edge, whereas GM1-rich rafts containing integrin $\beta 1$ are present at their uropod [2].

In 1996, platelet DRM was shown to be rich in glycoprotein CD36, Src, and Lyn [3]. Platelet rafts are important membrane microdomains in responses such as adhesion and aggregation. The localization of the adhesion receptor glycoprotein (GP)Ib-IX-V complex to lipid rafts is required for platelet adhesion to the vessel wall by binding the von Willebrand factor (vWF) $[4,5]$. In resting platelets, phosphatidylserine (PS) is asymmetrically restricted to the inner leaflet of the plasma membrane. An increase in intracellular $\mathrm{Ca}^{2+}$ concentration during platelet activation can lead to the exposure of PS in the outer leaflet. PS forms a procoagulant binding site for tenase and prothrombinase coagulation 
complexes. Lipid rafts are required for the release of PS-exposing extracellular vesicles from platelets [6]. Thus, lipid rafts are critical membrane domains in platelet activation processes $[7,8]$. Interestingly, platelet DRM shifts to a higher density in sucrose gradients upon thrombin receptor activating peptide (TRAP) stimulation [9]. Trace amounts of actin are observed in rafts from resting platelets, but a marked increase in the amount of actin is found in rafts upon platelet stimulation by TRAP. Platelet DRM also shifts to a higher density in sucrose gradients upon adenosine diphosphate (ADP) stimulation [10].

A protease-nicked and biotinylated derivative $(\mathrm{BC} \theta)$ of perfringolysin $\mathrm{O}$ ( $\theta$-toxin) binds specifically to cholesterol-rich microdomains of intact cells [11]. In resting platelets, $\mathrm{BC} \theta$-positive cholesterol-rich rafts are uniformly distributed on the cell surface. Upon interaction with fibrinogen, $\mathrm{BC} \theta$-positive cholesterol-rich rafts accumulate at the tips of filopodia and at the leading edge of spreading platelets [12]. The adhesion-dependent raft aggregation is accompanied by the concentration of the tyrosine kinase c-Src and the tetraspanin CD63 in cholesterol-rich rafts. The perfringolysin O derivative $\mathrm{BC} \theta$ recognizes a subpopulation (cholesterol-rich rafts) of platelet DRM rafts, suggesting that a heterogeneous population of lipid rafts exists in platelets [11]. However, little is known about raft heterogeneity in platelet membranes.

\section{Sphingomyelin-Rich Rafts of Platelets}

We have been identifying glycosphingolipid-binding proteins [13-19] and investigated the signal transduction in lipid rafts of platelets [20]. Previously, we reported that clot retraction is mediated by the coagulation factor XIII (FXIII)-dependent fibrin-integrin $\alpha \mathrm{IIb} \beta 3$-myosin axis in platelet sphingomyelin (SM)-rich membrane rafts [21]. Clot retraction is a process driven by outside-in signaling by the platelet integrin $\alpha \mathrm{Ilb} \beta 3$, resulting in the contraction of the fibrin mesh and the formation of mechanically stable thrombi. To elucidate the function of platelet lipid rafts, we identified DRM-raft-specific proteins from activated platelets. We isolated the DRM raft fraction of platelets treated with thrombin by sucrose gradient centrifugation. Several specific proteins were present in the DRM fraction of thrombin-stimulated platelets. By mass spectrometry, we identified three proteins of 65,50 , and $47 \mathrm{kDa}$ as fibrins $\alpha, \beta$, and $\gamma$, respectively. These findings were supported by the results of immunoblot analysis using an anti-fibrinogen/fibrin polyclonal antibody. In resting platelets, fibrinogens $\mathrm{A} \alpha$ $(67 \mathrm{kDa}), \mathrm{B} \beta(52 \mathrm{kDa})$, and $\gamma(47 \mathrm{kDa})$ were present in the non-raft fraction. In contrast, fibrins $\alpha(65 \mathrm{kDa}), \beta(50 \mathrm{kDa})$, and $\gamma(47 \mathrm{kDa})$ were exclusively present in the DRM fraction of platelets treated with thrombin (Figure 1A) [21]. Therefore, we investigated the subcellular distribution of fibrin and $\mathrm{BC} \theta$-positive cholesterol-rich rafts on thrombin-stimulated spreading platelets by scanning immunoelectron microscopy. Fibrin was localized in the central area of spreading platelet (Figure 1B, left panel). In contrast, $\mathrm{BC} \theta$-positive cholesterol-rich rafts were localized evenly on the membrane (Figure 1B, right panel). These observations suggest that fibrin is translocated to platelet rafts other than cholesterol-rich rafts following thrombin stimulation.

Lysenin, the earthworm toxin, is a specific probe of sphingomyelin (SM)-rich rafts in living cells [22,23]. SM is a major component of raft lipids in platelets [9]. Therefore, we investigated the subcellular distribution of SM-rich rafts in spreading platelets. Lysenin-positive SM-rich rafts were localized in the central area of adhering platelets stimulated with thrombin (Figure 2A, left panel). Lysenin-positive SM-rich rafts and fibrin mostly colocalized as a patch in the double-stained the central area of spreading platelets stimulated with thrombin (Figure 2A, middle panel). Next, we investigated the spreading of platelets by time-lapse differential interference contrast (DIC) imaging (Figure 2B) and lysenin staining (Figure 2C). In resting platelets (Figure 2C, $0 \mathrm{~min}$ ), lysenin-positive SM-rich rafts were uniformly distributed on the cell surface. At an early stage of the spreading of platelets treated with thrombin for $3 \mathrm{~min}$, SM-rich rafts were mainly localized in the central area of adhering platelets with some distributed in the lamellipodia. At a late stage of spreading of platelets treated with thrombin for $15 \mathrm{~min}$, almost all SM-rich rafts were in the central area. Furthermore, we also demonstrated the translocation of myosin to the DRM raft fraction following thrombin stimulation and the colocalization of activated myosin with fibrin in SM-rich rafts of adhering platelets stimulated with thrombin [21]. 
These observations suggest that SM-rich rafts act as platforms of fibrin-mediated outside-in signaling, leading to clot retraction. To support this idea, the clot retraction of SM-depleted platelets from SM synthase 1 and SM synthase 2 knockout mice was delayed significantly. As a result, we demonstrated that fibrin converted by thrombin translocates immediately into platelet DRM rafts in a coagulation factor XIII (FXIII)-dependent manner. Therefore, we proposed that fibrin is translocated to SM-rich rafts in the presence of FXIII crosslinking activity and that platelet SM-rich rafts act as platforms where extracellular fibrin and intracellular actomyosin join to promote clot retraction [21,24,25]. A spatial distinction between SM-rich rafts and cholesterol-rich rafts in platelets is illustrated (Figure 3).

A
Resting
Thrombin

1234567891012345678910 Fraction No.
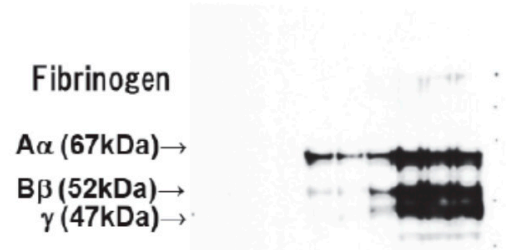

and
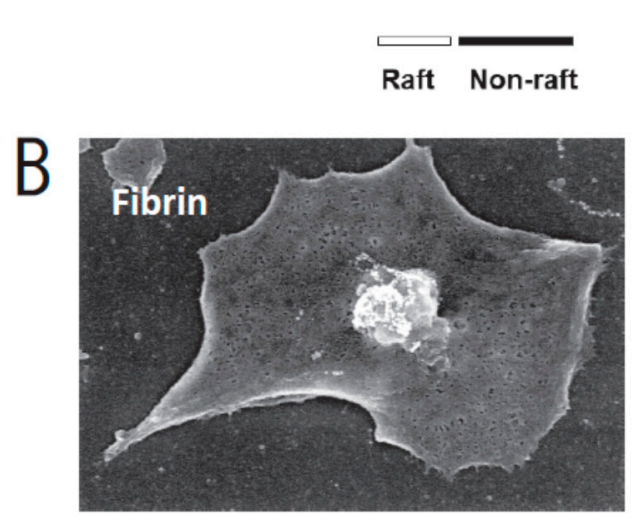

$\mathrm{kDa}$

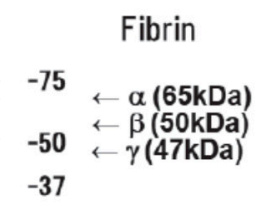

$-25$

Fibrinogen/Fibrin immunoblotting

Figure 1. Fibrin translocation to lipid rafts in central region of spreading platelets stimulated with thrombin. (A) Sucrose density gradient analysis of washed human platelets. Resting platelets (left) and platelets stimulated for $3 \mathrm{~min}$ with $1 \mathrm{U} / \mathrm{mL}$ thrombin (right) were lysed in Triton X-100 and then adjusted to $40 \%$ sucrose. A sucrose gradient (5-30\%) in a volume of $6 \mathrm{~mL}$ was layered over the lysate $(4 \mathrm{~mL})$ and was centrifuged. Ten fractions were collected from top to bottom after centrifugation and subjected to immunoblotting with an anti-fibrinogen polyclonal antibody. In resting platelets, fibrinogens $\mathrm{A} \alpha(67 \mathrm{kDa}), \mathrm{B} \beta(52 \mathrm{kDa})$, and $\gamma(47 \mathrm{kDa})$ were detected in the non-raft fraction (lanes $7-10)$. In contrast, fibrins $\alpha(65 \mathrm{kDa}), \beta(50 \mathrm{kDa})$, and $\gamma(47 \mathrm{kDa})$ were detected in the raft fraction (lanes 5,6) of thrombin-stimulated platelets. (B) Localization of fibrin (left panel) and BC $\theta$-positive cholesterol-rich rafts (right panel) of thrombin-stimulated spreading platelets on fibronectin by scanning immunoelectron microscopy. Spreading platelets were incubated with $15 \mu \mathrm{g} / \mathrm{mL} \mathrm{BC} \theta$ for $30 \mathrm{~min}$ followed by glutaraldehyde fixation and immunolabeling with anti-biotin IgG gold. Gold-positive fibrins were localized in the central region of spreading platelet (left). In contrast, gold-positive cholesterol-rich rafts were localized uniformly on the membrane (right). The study was approved by the institutional ethics committee. 
A

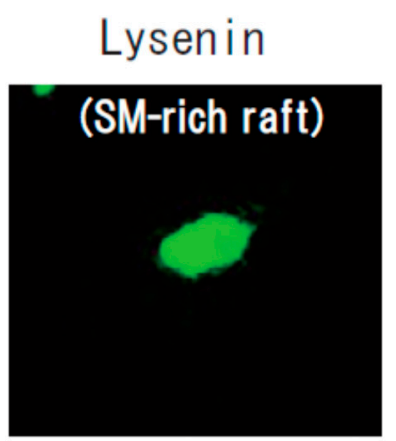

Fibrin

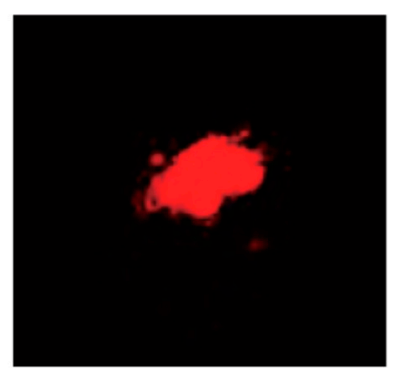

B Time-lapse platelet spreading

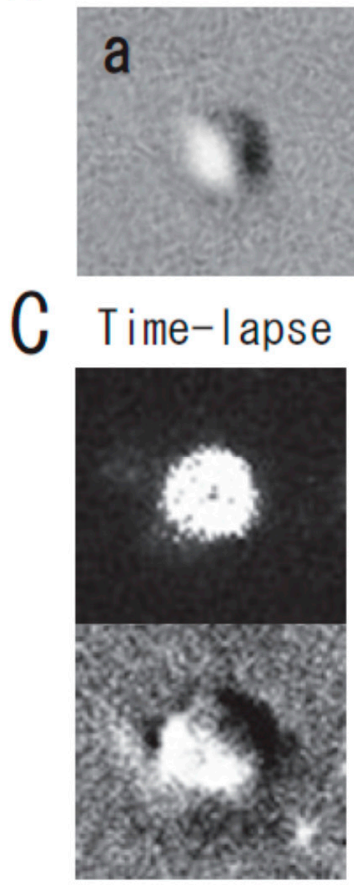

$0 \mathrm{~min}$
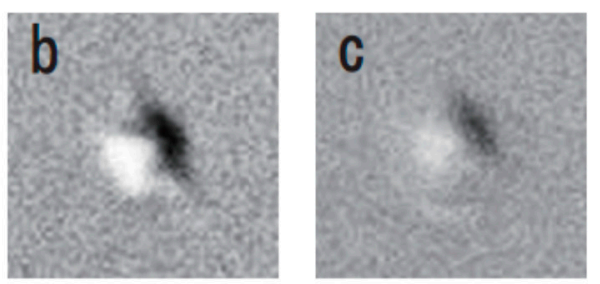

ysenin staining

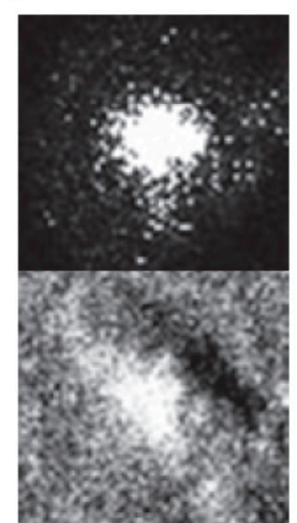

$3 \mathrm{~min}$

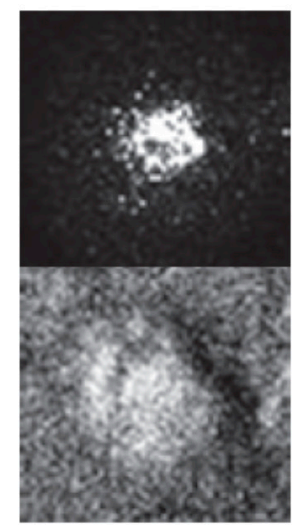

$5 \mathrm{~min}$
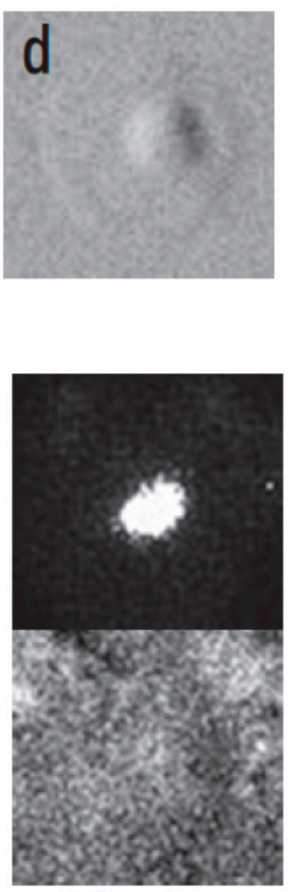

$15 \min$

Figure 2. Immunocytochemical colocalization of fibrin with sphingomyelin-rich rafts in central region of spreading platelets stimulated with thrombin. (A) Immunocytochemical colocalization of fibrin with sphingomyelin-rich rafts in central region of thrombin-stimulated spreading platelets. Green fluorescent protein (GFP)-lysenin-positive sphingomyelin-rich rafts (left panel). Alexa 594-labeled fibrin (middle panel). Phase contrast (right panel). Scale bar, $3 \mu \mathrm{m}$. (B) Time-lapse platelet spreading after thrombin stimulation on fibronectin-coated glass strip. (a) $0 \mathrm{~min}$; (b) $0.2 \mathrm{~min}$, filopodia formation; (c) $2 \mathrm{~min}$, spreading; (d) 10 min, complete spreading. (C) Time-lapse lysenin-positive sphingomyelin-rich raft staining. Washed platelets were incubated with GFP-lysenin for $10 \mathrm{~min}$ and then stimulated with $1 \mathrm{U} / \mathrm{mL}$ thrombin. The time-lapse fluorescent and DIC images were captured using Olympus LCV110. 

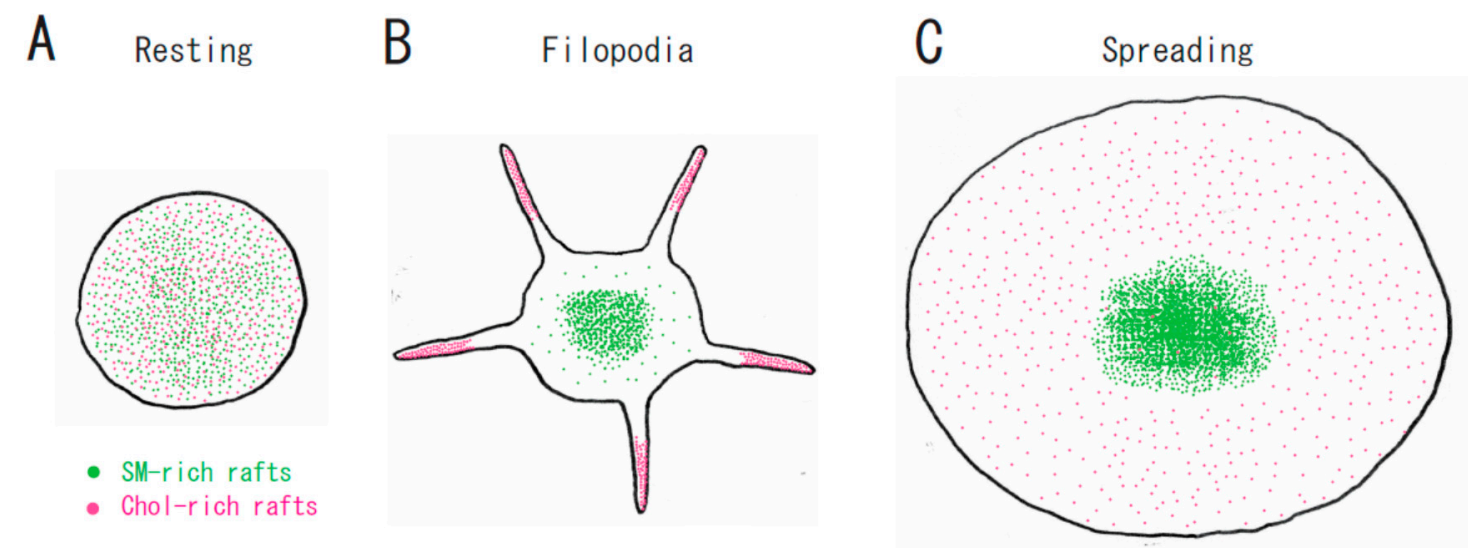

Figure 3. A spatial distinction between SM-rich rafts and cholesterol-rich rafts in platelets. (A) In resting platelets, SM-rich rafts (green) and cholesterol-rich rafts (red) are uniformly distributed on the cell surface. No spatial distinction is observed by confocal microscopy. (B) Cholesterol-rich rafts accumulate at the tips of filopodia of adhering platelets [12]. SM-rich rafts are mainly localized in the central area of adhering platelets with some distributed in the lamellipodia. (C) SM-rich rafts are in the central area of full spreading platelets. Cholesterol-rich rafts were localized evenly on the membrane [21].

\section{Raft Heterogeneity}

Platelet DRM shifts to a higher density in sucrose gradients upon platelet activation, suggesting that platelet lipid rafts are dynamic membrane microdomains. Not only actin and fibrin but also small GTPases (Rac, cdc42) and cytoskeleton regulatory proteins (moesin, Arp3, VASP) were detected in the DRM fraction of activated platelets [9]. The possible mechanism of the DRM shift to a higher density in sucrose gradients upon platelet activation presumably involves the high protein-to-lipid ratio [26].

In porcine lung membranes, two distinct types of DRM were obtained after sucrose density gradient centrifugation using Triton X-100. Light DRM contained cerebroside, whereas dense DRM contained $\mathrm{Ca}^{2+}$ ATPase and the IP3 receptor [27]. In the adult mouse cerebellum, two distinct types of DRM were also obtained after sucrose density gradient centrifugation using Triton X-100. Light DRM contained cerebroside and sulfatide [28]. In B-lymphocytes, two distinct types of DRM were obtained after sucrose density gradient centrifugation using Brij 98. Light DRM contained ganglioside GM1 and MHC II, whereas dense DRM contained ganglioside GM2 and MHC I [29]. These results suggest endocytosis of MHC molecules by distinct lipid rafts. In HEK293T cells, two distinct types of DRM were also obtained after sucrose density gradient centrifugation using sodium carbonate ( $\mathrm{pH} 11)$. Light DRM contained ganglioside GM1, whereas dense DRM contained cholesterol and flotillins [30]. Therefore, the platelet DRM shifts in sucrose gradients might be due to changes in lipid composition. Lactosylceramide and ganglioside GM3 are the major glycosphingolipids of human platelets [31]. Resting platelets do not express ganglioside GD3. The stimulation of platelets with ADP resulted in the formation of ganglioside GD3 by GD3 synthesis from the GM3 pool [31,32]. The GD3 synthase is CMP-NeuAc:NeuAc $\alpha 2-3 \mathrm{Gal} \beta 1-4 \mathrm{Glc} \beta 1-1^{\prime} \mathrm{Cer} \alpha 2,8$-sialyltransferase [33]. The stimulation of platelets with thrombin showed an increase in the amount of ganglioside GM3 [34]. The stimulation of platelets with ADP showed a decrease in the amount of cholesterol in the DRM raft fraction [10]. The precise mechanism of DRM shifts to a higher density in sucrose gradients upon platelet activation remains to be elucidated.

\section{Platelet Glycosphingolipids}

Lactosylceramide is the most abundant neutral glycosphingolipid. Its major fatty acids are 20:0, 22:0, 24:0, and 24:1. Ganglioside GM3 is the most abundant acidic glycosphingolipid. The neuraminic acid component was $\mathrm{N}$-acetylneuraminic acid [35,36]. In addition, galactosylceramide [36], 
sulfatide [37], glucosylceramide [34,38], ganglioside GM1 [39], globotriaosylceramide Gb3 [40], and sialyl-galactosylgloboside [41] are also found in human platelets.

Sulfatide is present on platelet surfaces that bind to adhesive proteins such as vWF, P-selectin, laminin, and thrombospondin [42,43]. Sulfatide is localized as a large cluster towards the center of spreading platelets [44], suggesting that sulfatide-rich rafts may be platforms involved in intracellular signaling. Sulfatide micelles, the sulfatide-binding recombinant malaria circumsporozoite protein (MCSP), and the sulfatide-specific single-chain fragment variable antibody probe PA38 inhibit this adhesion [44-46]. The sulfatide antagonist MCSP reverses platelet aggregation induced by ADP, collagen, or TRAP [45]. Sulfatide-deficient mice display an extended lag phase of collagen-induced platelet aggregation [44].

The adaptor protein Disabled-2 (Dab2) as a key regulator of platelet signaling is a sulfatide-binding protein. Its interaction is mediated by two $\mathrm{N}$-terminal conserved basic motifs (amino acid residues 24-29 and 49-54) with a dissociation constant $\mathrm{Kd}$ of $0.6 \mu \mathrm{M}$ [47]. Dab2 is present in the cytoplasm and $\alpha$-granules of platelets and is released from the platelets in response to platelet activation. Dab2 interacts with the cytoplasmic tail of the integrin $\alpha \mathrm{Ilb} \beta 3$ and regulates inside-out signaling [48]. On the other hand, Dab2 released from $\alpha$-granules inhibit platelet aggregation by competing with fibrinogen for binding to the integrin $\alpha \mathrm{Ilb} \beta 3$, an interaction that is modulated by Dab2 binding to sulfatide at the outer leaflet of the plasma membrane. The Dab2 sulfatide-binding motif peptide can prevent sulfatide-induced platelet aggregation $[49,50]$. The bleeding time is prolonged and thrombus formation is impaired in Dab2-deficient mice. Dab2-deficient platelets elicited a selective defect in platelet aggregation and spreading on fibrinogen by thrombin stimulation [51].

Sulfatide on the platelet surface interacts with a blood coagulation factor, playing a major role in hemostasis. Blood coagulation cascade has two pathways: intrinsic pathway and extrinsic pathway. Coagulation factor XII is a plasma serine protease that initiates the intrinsic pathway of blood coagulation upon contact with anionic surfaces, such as sulfatide on the plasma membrane. Annexins (ANXs) are implicated in the regulation of blood coagulation reactions by binding to sulfatide [52]. ANXA3, ANXA4, and ANXA5 inhibit sulfatide-induced plasma coagulation. ANXA4 inhibits sulfatide-induced autoactivation of Factor XII to Factor XIIa and the conversion of its natural substrate Factor XI to Factor XIa [53].

Ganglioside GD3 is rapidly expressed on the platelet surface following platelet activation and internalized to the cytoskeleton where it transiently associates first with the Src family kinase Lyn then with the Fc receptor gamma chain [32]. The binding of bacterial cells to human platelets contributes to the pathogenesis of infective endocarditis. Platelet binding by Streptococcus mitis strain SF100 is mediated by two surface proteins, $\mathrm{PblA}$ and $\mathrm{PblB}$. $\alpha 2$-8-linked sialic acid residues on platelet membrane ganglioside GD3 are the primary targets for PblA/PblB-mediated binding to human platelets. [54].

Globotriaosylceramide Gb3 is a functional receptor of the Shiga toxin [40]. Shiga toxin is the principal virulence factor of enterohemorrhagic Escherichia coli. Thrombocytopenia caused by platelet consumption in thrombi is a primary symptom of hemolytic uremic syndrome associated with Shiga toxin. Shiga toxin1 and its B (binding) subunit bind to platelets, leading to fibrinogen binding and platelet aggregation [55]. The possible existence of glycosphingolipid-specific rafts, such as sulfatide-rich rafts, remains to be explored.

\section{Platelet Raft-Binding Proteins}

Platelet rafts function as dynamic membrane microdomains for the attachment of various proteins such as adhesion molecules, receptors, signaling molecules, adaptor proteins, and effector proteins (Table 1). 
Table 1. Platelet raft-binding proteins.

\begin{tabular}{|c|c|c|c|c|c|}
\hline Molecules & Function & $\begin{array}{l}\text { Localization } \\
\text { in Rafts }\end{array}$ & $\begin{array}{c}\text { Moves into } \\
\text { Rafts }\end{array}$ & Palmitoylation & Ref. \\
\hline Actin & Cytoskeleton & + & & & [9] \\
\hline $\mathrm{ACV} / \mathrm{VI}$ & Adenylyl cyclase & & PGI2 & O & [56] \\
\hline Akt2 & Ser/Thr kinase & + & & & [20] \\
\hline Arp3 & Actin nucleator & & TRAP & & [9] \\
\hline Caveolin-1 & Integral scaffolding protein & ++ & & ○ & [57] \\
\hline CD9 & Tetraspanin & ++ & & $\bigcirc$ & [58] \\
\hline CD36 & Scavenger receptor & +++ & & $\mathrm{O}$ & [59] \\
\hline CD63 & Tetraspanin & ++ & & $\bigcirc$ & [58] \\
\hline Cdc42 & Small G protein & & TRAP & $\mathrm{O}$ & [9] \\
\hline CLEC-2 & Podoplanin receptor & & Rhodocytin & & [60] \\
\hline $\mathrm{c}-\mathrm{Src}$ & Tyr kinase & ++ & & & [12] \\
\hline CXCR4 & Chemokine receptor & + & & & [20] \\
\hline $\begin{array}{l}\text { Estrogen } \\
\text { receptor }\end{array}$ & Hormone receptor & & Estradiol & & [61] \\
\hline Factor XI & Plasma thromboplastin & ++ & & & [62] \\
\hline Factor XIII & Transglutaminase & & Thrombin & & [21] \\
\hline Fc receptor $g$ & Immunoglobulin G receptor & ++ & & & [63] \\
\hline Fibrin & Major component of blood clot & & Thrombin & & [21] \\
\hline Flotillin-1 & SPFH-domain scaffolding protein & +++ & & $\bigcirc$ & [59] \\
\hline Flotillin-2 & SPFH-domain scaffolding protein & +++ & & $\mathrm{O}$ & [64] \\
\hline Gia & Trimeric $G$ protein & ++ & & $\mathrm{O}$ & [65] \\
\hline GLUT-3 & Glucose transporter & ++ & & & [59] \\
\hline GP130 & IL6 receptor & ++ & & & [66] \\
\hline $\mathrm{GPIb} / \mathrm{IX} / \mathrm{V}$ & vWF receptor & & vWF & $\bigcirc$ & [4] \\
\hline GPVI & Collagen receptor & & Collagen & & [67] \\
\hline $\begin{array}{l}\text { Integrin } \\
\text { allbb3 }\end{array}$ & Fibrinogen receptor & + & & & [21] \\
\hline LAT & Linker for activation of T cells & +++ & & O & [68] \\
\hline Lyn & Tyr kinase & ++ & & $\mathrm{O}$ & [69] \\
\hline Moesin & ERM family & & TRAP & & [9] \\
\hline Myosin & Cytoskeleton & & Thrombin & & [21] \\
\hline Orai1 & Store-operated $\mathrm{Ca}^{2+}$ entry & ++ & & & [70] \\
\hline $\mathrm{P} 2 \mathrm{X} 1$ & ATP receptor & ++ & & & [64] \\
\hline $\mathrm{P} 2 \mathrm{Y} 1$ & ADP receptor & & ADP & & [10] \\
\hline P2Y12 & ADP receptor & & ADP & & [10] \\
\hline PECAM-1 & Adhesion molecule & ++ & & O & [63] \\
\hline $\mathrm{PI} 3 \mathrm{~Kb}$ & Phosphatidylinositol 3-kinase & + & & & [20] \\
\hline PI4K55 & Phosphatidylinositol 4-kinase & ++ & & ○ & [58] \\
\hline PKA-I & Ser/Thr kinase & & PGI2 & & [56] \\
\hline PP1c & Protein phosphatase & & Thrombin & & [71] \\
\hline PP2Ac & Protein phosphatase & & Thrombin & & [71] \\
\hline Prohibitin & SPFH-domain scaffolding protein & ++ & & O & [72] \\
\hline $\operatorname{PrPc}$ & Prion & + & & & [73] \\
\hline Pyk2 & Tyr kinase & ++ & & & [61] \\
\hline Rap2b & Small G protein & ++ & & ○ & [74] \\
\hline STIM1 & Store-operated $\mathrm{Ca}^{2+}$ entry & ++ & & & [70] \\
\hline Stomatin & SPFH-domain scaffolding protein & ++ & & O & [59] \\
\hline TIIICBP & Collagen receptor & ++ & & & [75] \\
\hline TRPC $1,4,5$ & Store-operated $\mathrm{Ca}^{2+}$ entry & ++ & & $\bigcirc$ & [76] \\
\hline $\begin{array}{l}\text { TXA2 } \\
\text { receptor }\end{array}$ & Prostanoid receptor & ++ & & $\bigcirc$ & [77] \\
\hline VASP & Actin filament elongation & & TRAP & & [9] \\
\hline vWF & Molecular glue of platelet plug & ++ & & & {$[4]$} \\
\hline $14-3-3 \zeta$ & pSer/pThr binding protein & & Cold shock & & [78] \\
\hline
\end{tabular}

Ratio (localization in rafts/non-rafts) +: low, ++: medium, +++: high. 


\subsection{Protein S-Palmitoylation: Lipid Raft Targeting Modification}

S-palmitoylation is a posttranslational modification catalyzed by palmitoyl acyltransferases from the zincfinger and Asp-His-His-Cys domain-containing (DHHC) enzyme family. It is involved in the attachment of the saturated palmitoyl acyl chain (C16:0) delivered by palmitoyl-CoA to a cysteine residue [79-81]. DHHC4 and DHHC5 facilitate fatty acid uptake by palmitoylating and targeting CD36 to the plasma membrane [82]. DHHC5 palmitoylates flotillin-2 in neuronal cells [83]. DHHC2 affects palmitoylation, and functions of tetraspanins CD9 and CD151 [84]. The enzymatic removal of S-acyl modifications in mammalian cells is catalyzed by acyl protein thioesterase (APT) and APT can remove palmitate groups from palmitoylated proteins [80]. Two protein palmitoyl thioesterases (PPTs) have been described as being capable of catalyzing the removal of fatty acids from proteins, in other words, acyl protein thioesterase 1 (APT1), and palmitoyl protein thioesterase 1 (PPT1). APT1 is reported to depalmitoylate the alpha subunit of G proteins and LAT in vitro. APT1 is itself palmitoylated and contain a hydrophobic pocket to accept palmitoylated substrates.

Protein palmitoylation is a dynamic modification that regulates the lipid raft targeting of proteins [85]. The basic forces driving raft formation are lipid interactions. The saturated acyl chains and high acyl chain melting temperatures of glycosphingolipids mediate glycosphingolipid clustering in combination with cholesterol, which has the properties of a "liquid-ordered phase." In contrast, most phospholipids have unsaturated acyl chains, low melting temperatures, and the properties of a liquid-disordered phase. Lipid rafts are considered to exist as phase-separated domains. The linkage of membrane proteins to saturated acyl chains by palmitoylation is considered to facilitate the translocation of these proteins to lipid rafts.

Platelet raft marker proteins are characterized by multiple S-palmitoylations. For example, palmitoylation occurs on the two N-terminal and two C-terminal cysteines, in human CD36 corresponding to cysteine residues 3, 7, 464, and 468 [86]. Both cysteine pairs are intracellular and adjacent to transmembrane segments. LAT contains two palmitoylated cytoplasmic Cys residues adjacent to its transmembrane domain, Cys 26 and Cys 29 [81]. Caveolin-1 is S-palmitoylated on its three cysteine residues (Cys 133, Cys 143, and Cys 156). [87] Using a proteomic approach, 215 palmitoylated platelet proteins are identified [88]. Palmitoylated platelet-raft-binding proteins are indicated in Table 1.

\subsection{G protein-Coupled Receptors (P2Y1, P2Y12, CXCR4)}

Platelet activation by several agonists such as collagen, ADP, and thrombin is followed by platelet granule release, integrin $\alpha \mathrm{IIb} \beta 3$ activation, aggregation, and thrombus formation. All these processes are triggered by an increase in cytosolic $\mathrm{Ca}^{2+}$ concentration $\left(\left(\mathrm{Ca}^{2+}\right) \mathrm{i}\right) \cdot \mathrm{Ca}^{2+}$, diacylglycerol-regulated guanine nucleotide exchange factor $\mathrm{I}$, and protein kinase $\mathrm{C}$ have been shown to be critical elements that link increased $\left(\mathrm{Ca}^{2+}\right)$ to platelet secretion and integrin $\alpha \mathrm{Ilb} \beta 3$ activation (inside-out signaling). ADP induces multiple platelet responses via seven transmembrane $\mathrm{G}$ protein-coupled receptors, P2Y1, and P2Y12. Lipid raft integrity is required for the P2Y1 and P2Y12 signaling pathways. P2Y1 is translocated to the DRM raft fraction by in vitro stimulation with ADP [10]. Importantly, in vivo oral administration to rats with clopidogrel, a P2Y12 antagonist, induces disruption of P2Y12 oligomers and their partition removal from lipid rafts [89].

Platelets are a source of chemokine stromal cell-derived factor- $1 \alpha$ (SDF- $1 \alpha)$, which is stored in $\alpha$-granules. Platelet-derived SDF- $1 \alpha$ modulates paracrine mechanisms such as chemotaxis [90]. Platelet-derived SDF- $1 \alpha$ is also an autocrine activator of platelets through its receptor CXCR4 [91-94]. SDF- $1 \alpha$-induced platelet aggregation in inhibited by the pertussis toxin, suggesting that its effect is mediated by a pertussis-toxin-sensitive $G$ protein such as G $\alpha$ i. SDF- $1 \alpha$ induces platelet aggregation via phosphatidylinositol 3 kinase (PI3K)/Akt signaling pathway [20]. Furthermore, SDF- $1 \alpha$-induced platelet aggregation and Akt phosphorylation are inhibited by pretreatment with the raft-disrupting agent methyl- $\beta$-cyclodextrin. Sucrose density gradient analysis shows that CXCR4 $(35 \%)$, the heterotrimeric G proteins G $\alpha \mathrm{i}-1$ (93\%), G $\alpha \mathrm{i}-2$ (91\%), and G $\beta(50 \%)$ and PI3K $\beta(4 \%)$, and Akt2 (4.5\%) are localized in the DRM raft fraction. G $\alpha \mathrm{i}-1$ and $\mathrm{G} \alpha \mathrm{i}-2$ are S-palmitoylated on a cysteine residue (Cys3). SDF-1 $\alpha$ is 
highly expressed in atherosclerotic plaques [95], suggesting that platelet aggregation by SDF- $1 \alpha / C X C R 4$ axis contributes to the pathologies such as atherosclerosis. Surface expression of SDF- $1 \alpha$ on platelets is a biomarker in ischemic events [90]. The SDF-1 $\alpha$ expression level on platelets is elevated in patients with acute myocardial infarction [96].

\subsection{Stomatin, Prohibitin, Flotillin, and HflK/C (SPFH)-Domain Protein Family}

\subsubsection{Flotillin}

Flotillins are raft-associated integral membrane proteins and belong to the SPFH superfamily [97]. Flotillins bind the inner leaflet of a plasma membrane raft and serve as scaffolds facilitating the assembly of multiprotein complexes. Flotillin-1 and flotillin-2 have the same domain architecture, comprising two domains: the $\mathrm{N}$-terminal SPFH domain and the $\mathrm{C}$-terminal flotillin domain [98]. The SPFH and flotillin domains mediate inner membrane binding and oligomerization of flotillins, respectively. The membrane association of flotillins is determined by the acyl chain(s) attached and the interaction of protein hydrophobic regions with the cytosolic leaflet of membranes. Flotillin-1 is S-palmitoylated on Cys34 located within the first hydrophobic stretch (amino acids 10-36). Flotillin-2 is N-myristoylated on Gly2 and S-palmitoylated on three cysteine residues; Cys4, Cys19, and Cys20, which are located in the first hydrophobic region (amino acids 14-35). The second hydrophobic region locates in the middle part of the SPFH domain (amino acids 134-150/151). The binding of cholesterol by flotillins is mediated by the cholesterol recognition/interaction amino acid (CRAC) motif(s) located within the SPFH domain (amino acids 117-124 in flotillin-1; 120-127 and 157-169 in flotillin-2).

Platelets store sphingosine-1-phosphate (S1P) abundantly and release this bioactive lipid extracellularly upon stimulation $[99,100]$. S1P induces platelet shape change and aggregation reactions and stimulates vascular endothelial cell spreading and migration [101]. Platelet-derived S1P plays an important role in vascular biology. S1P is synthetized from sphingosine by sphingosine kinases. Recently, flotillin-1 and flotillin-2 have been shown to recruit sphingosine to lipid rafts and maintain cellular S1P levels [102]. Sphingosine binding is mediated by the SPFH domain of flotillins, but the exact identities of the hydrophobic sequences of the flotillins involved are not known. Flotillins also interact with numerous signaling proteins such as receptors, protein kinases, $G$ proteins, and adaptors [98]. Therefore, flotillin-based microdomains can serve as platforms mediating the formation of multiprotein complexes and transmembrane signal transduction at the plasma membrane.

\subsubsection{Stomatin}

Stomatin is a raft-associated integral membrane protein and belongs to the SPFH superfamily [103]. Stomatin is composed of the $N$-terminal 24-residue basic domain, hydrophobic intramembrane domain (residues 26-54), cholesterol recognition/interaction amino acid consensus (CRAC, residues 55-68), SPFH domain (residues 57-256), coiled-coil domain, oligomerization and lipid-raft-association domain (ORA, residues 263-273), and C-terminal domain. Stomatin is S-palmitoylated on Cys30 and Cys87. The $\alpha$-helical segments of stomatin flexibly move along with the membrane surface, with such movement potentially leading to membrane bending via lipid raft clustering through the formation of homo-oligomeric complexes of SPFH-domain proteins [97]. Stomatin is localized at the platelet $\alpha$-granular membrane. The lipid-raft marker proteins flotillin- 1 and flotillin- 2 are present in the plasma membrane but excluded from $\alpha$-granules. The activation of platelets by thrombin leads to translocation of stomatin to the plasma membrane [59]. Lipid raft-associated stomatin enhances cell fusion. With its unique molecular topology, stomatin forms molecular assemblies within lipid rafts, and promotes membrane fusion by modulating fusogenic protein engagement [104]. During platelet activation, the $\alpha$-granular membrane undergoes fusion with the platelet plasma membrane and granular secretion. Stomatin may have a role in the $\alpha$-granular membrane fusion. 


\subsubsection{Prohibitin}

Prohibitin is also a raft-associated integral membrane protein and belongs to theSPFH superfamily [105]. Prohibitins, comprising the two homologous members PHB1 and PHB2, are ubiquitously expressed and highly conserved. Prohibitin is composed of the $N$-terminal hydrophobic stretch, SPFH domain, and coiled-coil domain. Prohibitin is S-palmitoylated on Cys69 [106]. Prohibitins are distributed in lipid rafts, as determined by sucrose density centrifugation. In addition, prohibitins are associated with protease-activated receptor 1 (PAR1). Platelet aggregation, integrin $\alpha \mathrm{Ilb} \beta 3$ activation, granular secretion, and calcium mobilization stimulated by low-concentration thrombin are reduced by the blockade of prohibitins with anti-prohibitin antibody [72]. Prohibitins are involved in PAR1-mediated platelet aggregation.

\subsection{Tetraspanin Family}

Tetraspanins are a superfamily of cell-surface glycoproteins that are characterized by four transmembrane domains, intracellular $\mathrm{N}$ - and C-termini, and conserved sequence motifs within the larger of two extracellular regions. Tetraspanins are considered to function by self-associating to form a novel type of membrane microdomain, "tetraspanin-enriched microdomains (TEMs)". TEMs are physically and functionally distinct from lipid rafts [107]. However, gangliosides are a membrane component of TEM [108] and are involved in tetraspanin-partner interactions, as determined from the finding that the depletion of gangliosides affects the interaction between CD82 and its partners [109], suggesting that gangliosides play a critical role in the organization of TEMs. Therefore, TEMs are considered to be a subset of glycosphingolipid microdomains [110].

Tetraspanins are a family of 33 membrane proteins in humans. More than ten tetraspanins (CD9, CD63, CD81, CD82, CD151, and Tspan 2, Tspan 9, Tspan 14, Tspan 15, Tspan 18, Tspan 32, and Tspan 33) are identified in platelets by flow cytometry and proteomics. The relative expression ratio of tetraspanins CD9, CD151, Tspan9, and CD63 (listed in order of their abundance in human platelets) have been estimated at 50:7:3:1.

\subsubsection{CD9}

CD9 is found to be expressed at approximately 50,000 copies per platelet [111]. CD9 is a negative regulator on platelets, because the fibrinogen binding of integrin $\alpha \mathrm{IIb} \beta 3$ in response to platelet agonists is found to be mildly enhanced in CD9-deficient platelets, suggesting that CD9 limits the inside-out activation of this integrin [112]. CD9 is S-palmitoylated on six cysteine residues (Cys9, Cys78, Cys79, Cys87, Cys218, and Cys219), which are located in four internal juxta membrane regions [113].

\subsubsection{CD151}

CD151-deficient platelets exhibited impaired "outside-in" integrin $\alpha \operatorname{Ilb} \beta 3$ signaling with defective platelet aggregation by the protease-activated receptor 4 (PAR4) agonist peptides, collagen, and ADP; impaired platelet spreading on fibrinogen; and delayed kinetics of clot retraction in vitro [114]. Furthermore, tail bleeding assay shows longer bleeding times, leading to the three-fold loss of blood and a seven-fold increase in the incidence of rebleeding [115]. CD151 is S-palmitoylated on six cysteine residues (Cys 11,15,79,80, 242, and 243). The association of a palmitoylation-deficient CD151 with CD81 and CD63 is markedly attenuated, but the interaction of the $\alpha 3 \beta 1-C D 151$ complex with phosphatidylinositol 4-kinase was not affected [116]. 


\subsubsection{CD63}

In resting platelets, CD63 is localized on the membranes of $\alpha$-granules and dense granules. Following platelet activation and granule exocytosis, CD63 is expressed on the plasma membrane and colocalizes with the $\alpha \mathrm{Ilb} \beta 3-\mathrm{CD} 9$ complex. CD63-deficient platelets show slightly enhanced in vitro aggregation responses, but they do not affect thrombus formation in vivo [117]. Palmitoylation levels of CD63 and CD9 increase following thrombin activation.

\subsubsection{Tspan32}

Tspan32(TSSC6)-deficient platelets exhibit impaired clot retraction, platelet aggregation at lower doses of PAR4, and collagen and platelet spreading on fibrinogen. Tspan32-deficient mice exhibit longer bleeding times and an increase in rebleeding, as shown by tail bleeding assay [118].

\subsubsection{CD82}

CD82-deficient platelets display enhanced integrin $\alpha \mathrm{Ilb} \beta 3$ surface expression, adhesion, tyrosine kinase signaling on fibrinogen, and clot retraction. CD82-deficient mice exhibit reduced bleed times in vivo [119].

A major problem in tetraspanin research is how to determine whether a particular phenotype is due to a specific effect on tetraspanin. CD151 and Tspan32 are direct binding partners of $\alpha \mathrm{IIb} \beta 3$ and might enhance outside-in signaling by recruiting specific signaling proteins in a subset of glycosphingolipid microdomains.

\subsection{Calcium Channels (Orai 1, STIM, TRPC)}

Platelet activation and aggregation depend on the increase in $\left(\mathrm{Ca}^{2+}\right)$ i resulting from intracellular $\mathrm{Ca}^{2+}$ release followed by store-operated $\mathrm{Ca}^{2+}$ entry (SOCE) through $\mathrm{Ca}^{2+}$ release-activated channels [120]. SOCE is accomplished by the pore forming unit Orai and its regulator the stromal interaction molecule (STIM). STIM1 is a transmembrane protein essential for the activation of SOCE, a major $\mathrm{Ca}^{2+}$ influx mechanism. STIM1 is localized in the endoplasmic reticulum, communicating the $\mathrm{Ca}^{2+}$ concentration in the stores to plasma membrane channels. Lipid rafts are required for the inactivation of SOCE by extracellular $\mathrm{Ca}^{2+}$ mediated by the interaction between plasma-membrane-located STIM1 and Orai1 [70]. Orai1 is a novel candidate of the platelet palmitoylome [88].

Orai1 trafficking to the cell surface is impaired in Tspan18-deficient platelets, resulting in impaired $\mathrm{Ca}^{2+}$ signaling. Tspan18 may regulate the $\mathrm{Ca}^{2+}$ channel function of Orai1 at the cell surface by promoting its clustering [121]. A reduction in the rate of release and a maximal $\mathrm{Ca}^{2+}$ increase are observed in Tspan18-deficient platelets. Defective aggregation of Tspan18-deficient platelets is observed in response to a collagen-related peptide at an intermediate concentration. Tspan18-deficient platelet spreading is impaired on a collagen-related peptide but normal on fibrinogen.

Another family of plasma membrane $\mathrm{Ca}^{2+}$ channels, the transient receptor potential canonical (TRPC) channels, also contributes to sustained $\left(\mathrm{Ca}^{2+}\right)$ i elevation. TRPC1, TRPC4, and TRPC5 form a heteromultimer associated with platelet lipid raft domains, whereas TRPC3 and TRPC6 associate independently of lipid rafts [76]. TRPC5 is S-palmitoylated on Cys 181 in an intracellular loop [122].

Author Contributions: K.K. (Keisuke Komatsuya) wrote the manuscript, K.K. (Kei Kaneko) reviewed the manuscript, and K.K. (Kohji Kasahara) reviewed and edited the manuscript. All authors have read and agreed to the published version of the manuscript.

Funding: This research was funded by the Mizutani Foundation for Glycoscience: 180186.

Acknowledgments: We are indebted to Toshihide Kobayashi (INSERM) for providing lysenin. We are grateful to Yoshiko Ohno-Iwashita (Iwaki Meisei University) for providing BC $\theta$. We thank Hidenori Suzuki (Keio University) for immunoelectron microscopic study.

Conflicts of Interest: The authors declare no conflict of interest. The funders had no role in the design of the study; in the collection, analyses, or interpretation of data; in the writing of the manuscript, or in the decision to publish the results 


\section{Abbreviations}

$\begin{array}{ll}\text { ADP } & \text { adenosine diphosphate } \\ \text { ANX } & \text { annexin } \\ \text { APT } & \text { acyl protein thioesterase } \\ \text { BC } & \text { biotinylated derivative of perfringolysin O } \\ \text { CRAC } & \text { cholesterol recognition/interaction amino acid motif } \\ \text { Dab2 } & \text { disabled-2 } \\ \text { DHHC } & \text { Asp-His-His-Cys domain } \\ \text { DIC } & \text { differential interference contrast } \\ \text { DRM } & \text { detergent-resistant membrane } \\ \text { FXIII } & \text { coagulation factor XIII } \\ \text { GFP } & \text { green fluorescent protein } \\ \text { GP } & \text { glycoprotein } \\ \text { MCSP } & \text { malaria circumsporozoite protein } \\ \text { PAR1 } & \text { protease-activated receptor 1 } \\ \text { PAR4 } & \text { protease-activated receptor } 4 \\ \text { PGI2 } & \text { prostaglandin I2 } \\ \text { PI3K } & \text { phosphatidylinositol } 3 \text { kinase } \\ \text { PPT } & \text { palmitoyl protein thioesterase } \\ \text { PS } & \text { phosphatidylserine } \\ \text { S1P } & \text { sphingosine-1-phosphate } \\ \text { SDF-1 } \alpha & \text { chemokine stromal cell-derived factor-1 } \alpha \\ \text { SOCE } & \text { store-operated Ca2+ entry } \\ \text { SM } & \text { sphingomyelin } \\ \text { SPFH domain } & \text { stomatin, prohibitin, flotillin, and HflK/C } \\ \text { STIM } & \text { stromal interaction molecule } \\ \text { TEM } & \text { tetraspanin-enriched microdomain } \\ \text { TRAP } & \text { thrombin receptor activating peptide } \\ \text { TRPC } & \text { transient receptor potential canonical } \\ \text { TXA2 } & \text { stromal interaction molecule } \\ \text { vWF } & \text { von Willebrand factor } \\ & \end{array}$

\section{References}

1. Simons, K.; Gerl, M.J. Revitalizing membrane rafts: New tools and insights. Nat. Rev. Mol. Cell Biol. 2010, 11, 688-699. [CrossRef] [PubMed]

2. Gómez-Móuton, C.; Abad, J.L.; Mira, E.; Lacalle, R.A.; Gallardo, E.; Jiménez-Baranda, S.; Illa, I.; Bernad, A.; Mañes, S.; Martínez-A, C. Segregation of leading-edge and uropod components into specific lipid rafts during T cell polarization. Proc. Natl. Acad. Sci. USA 2001, 98, 9642-9647. [CrossRef] [PubMed]

3. Dorahy, D.J.; Lincz, L.F.; Meldrum, C.J.; Burns, G.F. Biochemical isolation of a membrane microdomain from resting platelets highly enriched in the plasma membrane glycoprotein CD36. Biochem. J. 1996, 319, 67-72. [CrossRef]

4. Shrimpton, C.N.; Borthakur, G.; Larrucea, S.; Cruz, M.A.; Dong, J.F.; López, J.A. Localization of the adhesion receptor glycoprotein Ib-IX-V complex to lipid rafts is required for platelet adhesion and activation. J. Exp. Med. 2002, 196, 1057-1066. [CrossRef] [PubMed]

5. Jin, W.; Inoue, O.; Tamura, N.; Suzuki-Inoue, K.; Satoh, K.; Berndt, M.C.; Handa, M.; Goto, S.; Ozaki, Y. A role for glycosphingolipid-enriched microdomains in platelet glycoprotein Ib-mediated platelet activation. J. Thromb. Haemost. 2007, 5, 1034-1040. [CrossRef] [PubMed]

6. Wei, H.; Malcor, J.M.; Harper, M.T. Lipid rafts are essential for release of phosphatidylserine-exposing extracellular vesicles from platelets. Sci. Rep. 2018, 8, 9987. [CrossRef]

7. Bodin, S.; Tronchère, H.; Payrastre, B. Lipid rafts are critical membrane domains in blood platelet activation processes. Biochim. Biophys. Acta 2003, 1610, 247-257. [CrossRef]

8. López, J.A.; del Conde, I.; Shrimpton, C.N. Receptors, rafts, and microvesicles in thrombosis and inflammation. J. Thromb. Haemost. 2005, 3, 1737-1744. [CrossRef] 
9. Bodin, S.; Soulet, C.; Tronchère, H.; Sié, P.; Gachet, C.; Plantavid, M.; Payrastre, B. Integrin-dependent interaction of lipid rafts with the actin cytoskeleton in activated human platelets. J. Cell Sci. 2005, 118, 759-769. [CrossRef]

10. Rabani, V.; Montange, D.; Meneveau, N.; Davani, S. Impact of ticagrelor on P2Y1 and P2Y12 localization and on cholesterol levels in platelet plasma membrane. Platelets 2018, 29, 709-715. [CrossRef]

11. Waheed, A.A.; Shimada, Y.; Heijnen, H.F.; Nakamura, M.; Inomata, M.; Hayashi, M.; Iwashita, S.; Slot, J.W.; Ohno-Iwashita, Y. Selective binding of perfringolysin O derivative to cholesterol-rich membrane microdomains (rafts). Proc. Natl. Acad. Sci. USA 2001, 98, 4926-4931. [CrossRef] [PubMed]

12. Heijnen, H.F.; Van Lier, M.; Waaijenborg, S.; Ohno-Iwashita, Y.; Waheed, A.A.; Inomata, M.; Gorter, G.; Möbius, W.; Akkerman, J.W.; Slot, J.W. Concentration of rafts in platelet filopodia correlates with recruitment of c-Src and CD63 to these domains. J. Thromb. Haemost. 2003, 1, 1161-1173. [CrossRef] [PubMed]

13. Kasahara, K.; Watanabe, Y.; Yamamoto, T.; Sanai, Y. Association of Src family tyrosine kinase Lyn with ganglioside GD3 in rat brain. Possible regulation of Lyn by glycosphingolipid in caveolae-like domains. J. Biol. Chem. 1997, 272, 29947-29953. [CrossRef] [PubMed]

14. Kasahara, K.; Watanabe, K.; Takeuchi, K.; Kaneko, H.; Oohira, A.; Yamamoto, T.; Sanai, Y. Involvement of gangliosides in glycosylphosphatidylinositol-anchored neuronal cell adhesion molecule TAG-1 signaling in lipid rafts. J. Biol. Chem. 2000, 275, 34701-34709. [CrossRef] [PubMed]

15. Kasahara, K.; Sanai, Y. Functional roles of glycosphingolipids in signal transduction via lipid rafts. Glycoconj. J. 2000, 17, 153-162. [CrossRef]

16. Kasahara, K.; Watanabe, K.; Kozutsumi, Y.; Oohira, A.; Yamamoto, T.; Sanai, Y. Association of GPI-anchored protein TAG-1 with src-family kinase Lyn in lipid rafts of cerebellar granule cells. Neurochem. Res. 2002, 27, 823-829. [CrossRef]

17. Yuyama, K.; Sekino-Suzuki, N.; Sanai, Y.; Kasahara, K. Translocation of activated heterotrimeric G protein Galpha (o) to ganglioside-enriched detergent-resistant membrane rafts in developing cerebellum. J. Biol. Chem. 2007, 282, 26392-26400. [CrossRef]

18. Sekino-Suzuki, N.; Yuyama, K.; Miki, T.; Kaneda, M.; Suzuki, H.; Yamamoto, N.; Yamamoto, T.; Oneyama, C.; Okada, M.; Kasahara, K. Involvement of gangliosides in the process of Cbp/PAG phosphorylation by Lyn in developing cerebellar growth cones. J. Neurochem. 2013, 124, 514-522. [CrossRef]

19. Miki, T.; Kaneda, M.; Iida, K.; Hasegawa, G.; Murakami, M.; Yamamoto, N.; Asou, H.; Kasahara, K. An anti-sulfatide antibody $\mathrm{O} 4$ immunoprecipitates sulfatide rafts including Fyn, Lyn and the G protein $\alpha$ subunit in rat primary immature oligodendrocytes. Glycoconj. J. 2013, 30, 819-823. [CrossRef]

20. Ohtsuka, H.; Iguchi, T.; Hayashi, M.; Kaneda, M.; Iida, K.; Shimonaka, M.; Hara, T.; Arai, M.; Koike, Y.; Yamamoto, N.; et al. SDF-1 $\alpha /$ CXCR4 Signaling in Lipid Rafts Induces Platelet Aggregation via PI3 Kinase-Dependent Akt Phosphorylation. PLoS ONE 2017, 12, e0169609. [CrossRef]

21. Kasahara, K.; Kaneda, M.; Miki, T.; Iida, K.; Sekino-Suzuki, N.; Kawashima, I.; Suzuki, H.; Shimonaka, M.; Arai, M.; Ohno-Iwashita, Y.; et al. Clot retraction is mediated by factor XIII-dependent fibrin- $\alpha \mathrm{IIb} \beta 3$-myosin axis in platelet sphingomyelin-rich membrane rafts. Blood 2013, 122, 3340-3348. [CrossRef] [PubMed]

22. Kiyokawa, E.; Baba, T.; Otsuka, N.; Makino, A.; Ohno, S.; Kobayashi, T. Spatial and functional heterogeneity of sphingolipid-rich membrane domains. J. Biol. Chem. 2005, 280, 24072-24084. [CrossRef] [PubMed]

23. Hullin-Matsuda, F.; Kobayashi, T. Monitoring the distribution and dynamics of signaling microdomains in living cells with lipid-specific probes. Cell. Mol. Life Sci. 2007, 64, 2492-2504. [CrossRef] [PubMed]

24. Kasahara, K.; Souri, M.; Kaneda, M.; Miki, T.; Yamamoto, N.; Ichinose, A. Impaired clot retraction in factor XIII A subunit-deficient mice. Blood 2010, 115, 1277-1279. [CrossRef] [PubMed]

25. Munday, A.D.; López, J.A. Factor XIII: Sticking it to platelets. Blood 2013, 122, 3246-3247. [CrossRef] [PubMed]

26. Hrdinka, M.; Otahal, P.; Horejsi, V. The transmembrane region is responsible for targeting of adaptor protein LAX into "heavy rafts". PLoS ONE 2012, 7, e36330. [CrossRef]

27. Parkin, E.T.; Turner, A.J.; Hooper, N.M. Isolation and characterization of two distinct low-density, Triton-insoluble, complexes from porcine lung membranes. Biochem. J. 1996, 319, 887-896. [CrossRef]

28. Olive, S.; Dubois, C.; Schachner, M.; Rougon, G. The F3 neuronal glycosylphosphatidylinositol-linked molecule is localized to glycolipid-enriched membrane subdomains and interacts with L1 and fyn kinase in cerebellum. J. Neurochem. 1995, 65, 2307-2317. [CrossRef] 
29. Knorr, R.; Karacsonyi, C.; Lindner, R. Endocytosis of MHC molecules by distinct membrane rafts. J. Cell Sci. 2009, 122, 1584-1594. [CrossRef]

30. Jang, D.; Kwon, H.; Jeong, K.; Lee, J.; Pak, Y. Essential role of flotillin-1 palmitoylation in the intracellular localization and signaling function of IGF-1 receptor. J. Cell Sci. 2015, 128, 2179-2190. [CrossRef]

31. Ferroni, P.; Lenti, L.; Martini, F.; Ciatti, F.; Pontieri, G.M.; Gazzaniga, P.P. Ganglioside content of human platelets-differences in resting and activated platelets. Thromb. Haemost. 1997, 77, 548-554. [CrossRef] [PubMed]

32. Martini, F.; Riondino, S.; Pignatelli, P.; Gazzaniga, P.P.; Ferroni, P.; Lenti, L. Involvement of GD3 in platelet activation. A novel association with Fcgamma receptor. Biochim. Biophys. Acta 2002, 1583, 297-304. [PubMed]

33. Nara, K.; Watanabe, Y.; Maruyama, K.; Kasahara, K.; Nagai, Y.; Sanai, Y. Expression cloning of a CMP-NeuAc: NeuAc alpha 2-3Gal beta 1-4Glc beta 1-1'Cer alpha 2,8-sialyltransferase (GD3 synthase) from human melanoma cells. Proc. Natl. Acad. Sci. USA 1994, 91, 7952-7956. [CrossRef] [PubMed]

34. Wang, C.T.; Schick, P.K. The effect of thrombin on the organization of human platelet membrane glycosphingolipids. The sphingosine composition of platelet glycolipids and ceramides. J. Biol. Chem. 1981, 256, 752-756. [PubMed]

35. Tao, R.V.; Sweeley, C.C.; Jamieson, G.A. Sphingolipid composition of human platelets. J. Lipid Res. 1973, 14, 16-25. [PubMed]

36. Kyogashima, M.; Taketomi, T. Lipids from human platelets in primary thrombocythemia. Jpn. J. Exp. Med. 1986, 56, 113-118. [PubMed]

37. Kushi, Y.; Arita, M.; Ishizuka, I.; Kasama, T.; Fredman, P.; Handa, S. Sulfatide is expressed in both erythrocytes and platelets of bovine origin. Biochim. Biophys. Acta 1996, 1304, 254-262. [CrossRef]

38. Zdebska, E.; Soszyńska, B.; Dobrowolski, Z.; Kościelak, J. The levels of glycosphingolipids, ceramides, sialic acid and glycogen are changed in plasma membranes of rat platelets harvested during recovery from immune-mediated thrombocytopenia. Acta Biochim. Pol. 1996, 43, 547-555. [CrossRef]

39. Liu, L.; Zhang, K.; Tan, L.; Chen, Y.H.; Cao, Y.P. Alterations in cholesterol and ganglioside GM1 content of lipid rafts in platelets from patients with Alzheimer disease. Alzheimer Dis. Assoc. Disord. 2015, 29, 63-69. [CrossRef]

40. Cooling, L.L.; Walker, K.E.; Gille, T.; Koerner, T.A. Shiga toxin binds human platelets via globotriaosylceramide (Pk antigen) and a novel platelet glycosphingolipid. Infect. Immun. 1998, 66, 4355-4366. [CrossRef]

41. Cooling, L.L.; Zhang, D.; Koerner, T.A. Human platelets express gangliosides with LKE activity and ABH blood group activity. Transfusion 2001, 41, 504-516. [CrossRef] [PubMed]

42. Roberts, D.D.; Williams, S.B.; Gralnick, H.R.; Ginsburg, V. von Willebrand factor binds specifically to sulfated glycolipids. J. Biol. Chem. 1986, 261, 3306-3309. [PubMed]

43. Ginsburg, V.; Roberts, D.D. Glycoconjugates and cell adhesion: The adhesive proteins laminin, thrombospondin and von Willebrand's factor bind specifically to sulfated glycolipids. Biochimie 1988, 70, 1651-1659. [CrossRef]

44. Guchhait, P.; Shrimpton, C.N.; Honke, K.; Rumbaut, R.E.; Lopez, J.A.; Thiagarajan, P. Effect of an anti-sulfatide single-chain antibody probe on platelet function. Thromb. Haemost. 2008, 99, 552-557. [PubMed]

45. Merten, M.; Thiagarajan, P. Role for sulfatides in platelet aggregation. Circulation 2001, 104, $2955-2960$. [CrossRef] [PubMed]

46. Borthakur, G.; Cruz, M.A.; Dong, J.F.; McIntire, L.; Li, F.; López, J.A.; Thiagarajan, P. Sulfatides inhibit platelet adhesion to von Willebrand factor in flowing blood. J. Thromb. Haemost. 2003, 1, 1288-1295. [CrossRef] [PubMed]

47. Drahos, K.E.; Welsh, J.D.; Finkielstein, C.V.; Capelluto, D.G. Sulfatides partition disabled-2 in response to platelet activation. PLoS ONE 2009, 4, e8007. [CrossRef]

48. Tsai, H.J.; Tseng, C.P. The adaptor protein Disabled-2: New insights into platelet biology and integrin signaling. Thromb. J. 2016, 14 (Suppl. 1), 28. [CrossRef]

49. Welsh, J.D.; Charonko, J.J.; Salmanzadeh, A.; Drahos, K.E.; Shafiee, H.; Stremler, M.A.; Davalos, R.V.; Capelluto, D.G.; Vlachos, P.P.; Finkielstein, C.V. Disabled-2 modulates homotypic and heterotypic platelet interactions by binding to sulfatides. Br. J. Haematol. 2011, 154, 122-133. [CrossRef] 
50. Xiao, S.; Charonko, J.J.; Fu, X.; Salmanzadeh, A.; Davalos, R.V.; Vlachos, P.P.; Finkielstein, C.V.; Capelluto, D.G. Structure, sulfatide binding properties, and inhibition of platelet aggregation by a disabled-2 protein-derived peptide. J. Biol. Chem. 2012, 287, 37691-37702. [CrossRef]

51. Tsai, H.J.; Huang, C.L.; Chang, Y.W.; Huang, D.Y.; Lin, C.C.; Cooper, J.A.; Cheng, J.C.; Tseng, C.P. Disabled-2 is required for efficient hemostasis and platelet activation by thrombin in mice. Arterioscler. Thromb. Vasc. Biol. 2014, 34, 2404-2412. [CrossRef] [PubMed]

52. Ida, M.; Satoh, A.; Matsumoto, I.; Kojima-Aikawa, K. Human annexin V binds to sulfatide: Contribution to regulation of blood coagulation. J. Biochem. 2004, 135, 583-588. [CrossRef] [PubMed]

53. Nakayama, M.; Miyagawa, H.; Kuranami, Y.; Tsunooka-Ota, M.; Yamaguchi, Y.; Kojima-Aikawa, K. Annexin A4 inhibits sulfatide-induced activation of coagulation factor XII. J. Thromb. Haemost. 2020, 18, 1357-1369. [CrossRef] [PubMed]

54. Mitchell, J.; Sullam, P.M. Streptococcus mitis phage-encoded adhesins mediate attachment to \{alpha\} 2-8-linked sialic acid residues on platelet membrane gangliosides. Infect. Immun. 2009, 77, 3485-3490. [CrossRef]

55. Karpman, D.; Papadopoulou, D.; Nilsson, K.; Sjögren, A.C.; Mikaelsson, C.; Lethagen, S. Platelet activation by Shiga toxin and circulatory factors as a pathogenetic mechanism in the hemolytic uremic syndrome. Blood 2001, 97, 3100-3108. [CrossRef]

56. Raslan, Z.; Naseem, K.M. Compartmentalisation of cAMP-dependent signalling in blood platelets: The role of lipid rafts and actin polymerisation. Platelets 2015, 26, 349-357. [CrossRef]

57. Cerecedo, D.; Martínez-Vieyra, I.; Maldonado-García, D.; Hernández-González, E.; Winder, S.J. Association of membrane/lipid rafts with the platelet cytoskeleton and the caveolin PY14: Participation in the adhesion process. J. Cell. Biochem. 2015, 116, 2528-2540. [CrossRef]

58. Israels, S.J.; McMillan-Ward, E.M. Platelet tetraspanin complexes and their association with lipid rafts. Thromb. Haemost. 2007, 98, 1081-1087.

59. Mairhofer, M.; Steiner, M.; Mosgoeller, W.; Prohaska, R.; Salzer, U. Stomatin is a major lipid-raft component of platelet alpha granules. Blood 2002, 100, 897-904. [CrossRef]

60. Pollitt, A.Y.; Grygielska, B.; Leblond, B.; Désiré, L.; Eble, J.A.; Watson, S.P. Phosphorylation of CLEC-2 is dependent on lipid rafts, actin polymerization, secondary mediators, and Rac. Blood 2010, 115, 2938-2946. [CrossRef]

61. Reineri, S.; Bertoni, A.; Sanna, E.; Baldassarri, S.; Sarasso, C.; Zanfa, M.; Canobbio, I.; Torti, M.; Sinigaglia, F. Membrane lipid rafts coordinate estrogen-dependent signaling in human platelets. Biochim. Biophys. Acta 2007, 1773, 273-278. [CrossRef] [PubMed]

62. Baglia, F.A.; Shrimpton, C.N.; López, J.A.; Walsh, P.N. The glycoprotein Ib-IX-V complex mediates localization of factor XI to lipid rafts on the platelet membrane. J. Biol. Chem. 2003, 278, 21744-21750. [CrossRef] [PubMed]

63. Lee, F.A.; van Lier, M.; Relou, I.A.; Foley, L.; Akkerman, J.W.; Heijnen, H.F.; Farndale, R.W. Lipid rafts facilitate the interaction of PECAM-1 with the glycoprotein VI-FcR gamma-chain complex in human platelets. J. Biol. Chem. 2006, 281, 39330-39338. [CrossRef] [PubMed]

64. Vial, C.; Fung, C.Y.; Goodall, A.H.; Mahaut-Smith, M.P.; Evans, R.J. Differential sensitivity of human platelet P2X1 and P2Y1 receptors to disruption of lipid rafts. Biochem. Biophys. Res. Commun. 2006, 343, 415-419. [CrossRef] [PubMed]

65. Quinton, T.M.; Kim, S.; Jin, J.; Kunapuli, S.P. Lipid rafts are required in Galpha (i) signaling downstream of the P2Y12 receptor during ADP-mediated platelet activation. J. Thromb. Haemost. 2005, 3, 1036-1041. [CrossRef]

66. Houck, K.L.; Yuan, H.; Tian, Y.; Solomon, M.; Cramer, D.; Liu, K.; Zhou, Z.; Wu, X.; Zhang, J.; Oehler, V.; et al. Physical proximity and functional cooperation of glycoprotein 130 and glycoprotein VI in platelet membrane lipid rafts. J. Thromb. Haemost. 2019, 17, 1500-1510. [CrossRef]

67. van Lier, M.; Lee, F.; Farndale, R.W.; Gorter, G.; Verhoef, S.; Ohno-Iwashita, Y.; Akkerman, J.W.; Heijnen, H.F. Adhesive surface determines raft composition in platelets adhered under flow. J. Thromb. Haemost. 2005, 3, 2514-2525. [CrossRef]

68. Ezumi, Y.; Kodama, K.; Uchiyama, T.; Takayama, H. Constitutive and functional association of the platelet collagen receptor glycoprotein VI-Fc receptor gamma-chain complex with membrane rafts. Blood 2002, 99, 3250-3255. [CrossRef] 
69. Dorahy, D.J.; Burns, G.F. Active Lyn protein tyrosine kinase is selectively enriched within membrane microdomains of resting platelets. Biochem. J. 1998, 333, 373-379. [CrossRef]

70. Dionisio, N.; Galán, C.; Jardín, I.; Salido, G.M.; Rosado, J.A. Lipid rafts are essential for the regulation of SOCE by plasma membrane resident STIM1 in human platelets. Biochim. Biophys. Acta 2011, 1813, 431-437. [CrossRef]

71. Pradhan, S.; Vijayan, K.V. Lipid rafts contribute to agonist-induced serine/threonine phosphatase activation and platelet aggregation. J. Thromb. Haemost. 2013, 11, 1612-1615. [CrossRef] [PubMed]

72. Zhang, Y.; Wang, Y.; Xiang, Y.; Lee, W. Prohibitins are involved in protease-activated receptor 1-mediated platelet aggregation. J. Thromb. Haemost. 2012, 10, 411-418. [CrossRef] [PubMed]

73. Brouckova, A.; Holada, K. Cellular prion protein in blood platelets associates with both lipid rafts and the cytoskeleton. Thromb. Haemost. 2009, 102, 966-974. [CrossRef] [PubMed]

74. Canobbio, I.; Trionfini, P.; Guidetti, G.F.; Balduini, C.; Torti, M. Targeting of the small GTPase Rap2b, but not Rap1b, to lipid rafts is promoted by palmitoylation at Cys176 and Cys177 and is required for efficient protein activation in human platelets. Cell. Signal. 2008, 20, 1662-1670. [CrossRef]

75. Maurice, P.; Waeckel, L.; Pires, V.; Sonnet, P.; Lemesle, M.; Arbeille, B.; Vassy, J.; Rochette, J.; Legrand, C.; Fauvel-Lafève, F. The platelet receptor for type III collagen (TIIICBP) is present in platelet membrane lipid microdomains (rafts). Histochem. Cell Biol. 2006, 125, 407-417. [CrossRef]

76. Brownlow, S.L.; Sage, S.O. Transient receptor potential protein subunit assembly and membrane distribution in human platelets. Thromb. Haemost. 2005, 94, 839-845.

77. Moscardó, A.; Vallés, J.; Latorre, A.; Santos, M.T. The association of thromboxane A2 receptor with lipid rafts is a determinant for platelet functional responses. FEBS Lett. 2014, 588, 3154-3159. [CrossRef]

78. Gitz, E.; Koekman, C.A.; van den Heuvel, D.J.; Deckmyn, H.; Akkerman, J.W.; Gerritsen, H.C.; Urbanus, R.T. Improved platelet survival after cold storage by prevention of glycoprotein Ib $\alpha$ clustering in lipid rafts. Haematologica 2012, 97, 1873-1881. [CrossRef]

79. Iwanaga, T.; Tsutsumi, R.; Noritake, J.; Fukata, Y.; Fukata, M. Dynamic protein palmitoylation in cellular signaling. Prog. Lipid Res. 2009, 48, 117-127. [CrossRef]

80. Ko, P.J.; Dixon, S.J. Protein palmitoylation and cancer. EMBO Rep. 2018, 19, e46666. [CrossRef]

81. Ladygina, N.; Martin, B.R.; Altman, A. Dynamic palmitoylation and the role of DHHC proteins in T cell activation and anergy. Adv. Immunol. 2011, 109, 1-44. [PubMed]

82. Wang, J.; Hao, J.W.; Wang, X.; Guo, H.; Sun, H.H.; Lai, X.Y.; Liu, L.Y.; Zhu, M.; Wang, H.Y.; Li, Y.F.; et al. DHHC4 and DHHC5 Facilitate Fatty Acid Uptake by Palmitoylating and Targeting CD36 to the Plasma Membrane. Cell Rep. 2019, 26, 209-221.e205. [CrossRef] [PubMed]

83. Li, Y.; Martin, B.R.; Cravatt, B.F.; Hofmann, S.L. DHHC5 protein palmitoylates flotillin-2 and is rapidly degraded on induction of neuronal differentiation in cultured cells. J. Biol. Chem. 2012, 287, 523-530. [CrossRef] [PubMed]

84. Sharma, C.; Yang, X.H.; Hemler, M.E. DHHC2 affects palmitoylation, stability, and functions of tetraspanins CD9 and CD151. Mol. Biol. Cell 2008, 19, 3415-3425. [CrossRef] [PubMed]

85. Lorent, J.H.; Levental, I. Structural determinants of protein partitioning into ordered membrane domains and lipid rafts. Chem. Phys. Lipids 2015, 192, 23-32. [CrossRef]

86. Luiken, J.J.; Chanda, D.; Nabben, M.; Neumann, D.; Glatz, J.F. Post-translational modifications of CD36 (SR-B2): Implications for regulation of myocellular fatty acid uptake. Biochim. Biophys. Acta 2016, 1862, 2253-2258. [CrossRef]

87. Parton, R.G.; Hanzal-Bayer, M.; Hancock, J.F. Biogenesis of caveolae: A structural model for caveolin-induced domain formation. J. Cell Sci. 2006, 119, 787-796. [CrossRef]

88. Dowal, L.; Yang, W.; Freeman, M.R.; Steen, H.; Flaumenhaft, R. Proteomic analysis of palmitoylated platelet proteins. Blood 2011, 118, e62-e73. [CrossRef]

89. Savi, P.; Zachayus, J.L.; Delesque-Touchard, N.; Labouret, C.; Hervé, C.; Uzabiaga, M.F.; Pereillo, J.M.; Culouscou, J.M.; Bono, F.; Ferrara, P.; et al. The active metabolite of Clopidogrel disrupts P2Y12 receptor oligomers and partitions them out of lipid rafts. Proc. Natl. Acad. Sci. USA 2006, 103, 11069-11074. [CrossRef]

90. Chatterjee, M.; Gawaz, M. Platelet-derived CXCL12 (SDF-1 $\alpha$ ): Basic mechanisms and clinical implications. J. Thromb. Haemost. 2013, 11, 1954-1967. [CrossRef] 
91. Kowalska, M.A.; Ratajczak, J.; Hoxie, J.; Brass, L.F.; Gewirtz, A.; Poncz, M.; Ratajczak, M.Z. Megakaryocyte precursors, megakaryocytes and platelets express the HIV co-receptor CXCR4 on their surface: Determination of response to stromal-derived factor-1 by megakaryocytes and platelets. Br. J. Haematol. 1999, 104, 220-229. [CrossRef] [PubMed]

92. Kowalska, M.A.; Ratajczak, M.Z.; Majka, M.; Jin, J.; Kunapuli, S.; Brass, L.; Poncz, M. Stromal cell-derived factor-1 and macrophage-derived chemokine: 2 chemokines that activate platelets. Blood 2000, 96, 50-57. [CrossRef] [PubMed]

93. Chatterjee, M.; Seizer, P.; Borst, O.; Schönberger, T.; Mack, A.; Geisler, T.; Langer, H.F.; May, A.E.; Vogel, S.; Lang, F.; et al. SDF-1 $\alpha$ induces differential trafficking of CXCR4-CXCR7 involving cyclophilin A, CXCR7 ubiquitination and promotes platelet survival. FASEB J. 2014, 28, 2864-2878. [CrossRef] [PubMed]

94. Walsh, T.G.; Harper, M.T.; Poole, A.W. SDF-1 $\alpha$ is a novel autocrine activator of platelets operating through its receptor CXCR4. Cell. Signal. 2015, 27, 37-46. [CrossRef] [PubMed]

95. Abi-Younes, S.; Sauty, A.; Mach, F.; Sukhova, G.K.; Libby, P.; Luster, A.D. The stromal cell-derived factor-1 chemokine is a potent platelet agonist highly expressed in atherosclerotic plaques. Circ. Res. 2000, 86, 131-138. [CrossRef] [PubMed]

96. Geisler, T.; Fekecs, L.; Wurster, T.; Chiribiri, A.; Schuster, A.; Nagel, E.; Miller, S.; Gawaz, M.; Stellos, K.; Bigalke, B. Association of platelet-SDF-1 with hemodynamic function and infarct size using cardiac MR in patients with AMI. Eur. J. Radiol. 2012, 81, e486-e490. [CrossRef]

97. Yokoyama, H.; Matsui, I. The lipid raft markers stomatin, prohibitin, flotillin, and HflK/C (SPFH)-domain proteins form an operon with $\mathrm{NfeD}$ proteins and function with apolar polyisoprenoid lipids. Crit. Rev. Microbiol. 2020, 46, 38-48. [CrossRef]

98. Kwiatkowska, K.; Matveichuk, O.V.; Fronk, J.; Ciesielska, A. Flotillins: At the Intersection of Protein. Int. J. Mol. Sci. 2020, 21, 2283. [CrossRef]

99. Yatomi, Y.; Ruan, F.; Hakomori, S.; Igarashi, Y. Sphingosine-1-phosphate: A platelet-activating sphingolipid released from agonist-stimulated human platelets. Blood 1995, 86, 193-202. [CrossRef]

100. Yatomi, Y.; Ozaki, Y.; Ohmori, T.; Igarashi, Y. Sphingosine 1-phosphate: Synthesis and release. Prostaglandins Other Lipid Mediat. 2001, 64, 107-122. [CrossRef]

101. Okamoto, H.; Yatomi, Y.; Ohmori, T.; Satoh, K.; Matsumoto, Y.; Ozaki, Y. Sphingosine 1-phosphate stimulates G (i)- and Rho-mediated vascular endothelial cell spreading and migration. Thromb. Res. 2000, 99, 259-265. [CrossRef]

102. Riento, K.; Zhang, Q.; Clark, J.; Begum, F.; Stephens, E.; Wakelam, M.J.; Nichols, B.J. Flotillin proteins recruit sphingosine to membranes and maintain cellular sphingosine-1-phosphate levels. PLoS ONE 2018, 13, e0197401. [CrossRef] [PubMed]

103. Rungaldier, S.; Umlauf, E.; Mairhofer, M.; Salzer, U.; Thiele, C.; Prohaska, R. Structure-function analysis of human stomatin: A mutation study. PLoS ONE 2017, 12, e0178646. [CrossRef]

104. Lee, J.H.; Hsieh, C.F.; Liu, H.W.; Chen, C.Y.; Wu, S.C.; Chen, T.W.; Hsu, C.S.; Liao, Y.H.; Yang, C.Y.; Shyu, J.F.; et al. Lipid raft-associated stomatin enhances cell fusion. FASEB J. 2017, 31, 47-59. [CrossRef] [PubMed]

105. Morrow, I.C.; Parton, R.G. Flotillins and the PHB domain protein family: Rafts, worms and anaesthetics. Traffic 2005, 6, 725-740. [CrossRef] [PubMed]

106. Ande, S.R.; Mishra, S. Palmitoylation of prohibitin at cysteine 69 facilitates its membrane translocation and interaction with Eps 15 homology domain protein 2 (EHD2). Biochem. Cell Biol. 2010, 88, 553-558. [CrossRef]

107. Hemler, M.E. Tetraspanin proteins mediate cellular penetration, invasion, and fusion events and define a novel type of membrane microdomain. Annu. Rev. Cell Dev. Biol. 2003, 19, 397-422. [CrossRef]

108. van Deventer, S.J.; Dunlock, V.E.; van Spriel, A.B. Molecular interactions shaping the tetraspanin web. Biochem. Soc. Trans. 2017, 45, 741-750. [CrossRef]

109. Odintsova, E.; Butters, T.D.; Monti, E.; Sprong, H.; van Meer, G.; Berditchevski, F. Gangliosides play an important role in the organization of CD82-enriched microdomains. Biochem. J. 2006, 400, 315-325. [CrossRef]

110. Hakomori Si, S.I. The glycosynapse. Proc. Natl. Acad. Sci. USA 2002, 99, 225-232. [CrossRef]

111. Dale, G.L.; Remenyi, G.; Friese, P. Tetraspanin CD9 is required for microparticle release from coated-platelets. Platelets 2009, 20, 361-366. [CrossRef] [PubMed]

112. Mangin, P.H.; Kleitz, L.; Boucheix, C.; Gachet, C.; Lanza, F. CD9 negatively regulates integrin alphaIlbbeta3 activation and could thus prevent excessive platelet recruitment at sites of vascular injury. J. Thromb. Haemost. 2009, 7, 900-902. [CrossRef] [PubMed] 
113. .Charrin, S.; Manié, S.; Oualid, M.; Billard, M.; Boucheix, C.; Rubinstein, E. Differential stability of tetraspanin/tetraspanin interactions: Role of palmitoylation. FEBS Lett. 2002, 516, 139-144. [CrossRef]

114. Lau, L.M.; Wee, J.L.; Wright, M.D.; Moseley, G.W.; Hogarth, P.M.; Ashman, L.K.; Jackson, D.E. The tetraspanin superfamily member CD151 regulates outside-in integrin alphaIlbbeta3 signaling and platelet function. Blood 2004, 104, 2368-2375. [CrossRef]

115. Wright, M.D.; Geary, S.M.; Fitter, S.; Moseley, G.W.; Lau, L.M.; Sheng, K.C.; Apostolopoulos, V.; Stanley, E.G.; Jackson, D.E.; Ashman, L.K. Characterization of mice lacking the tetraspanin superfamily member CD151. Mol. Cell. Biol. 2004, 24, 5978-5988. [CrossRef]

116. Berditchevski, F.; Odintsova, E.; Sawada, S.; Gilbert, E. Expression of the palmitoylation-deficient CD151 weakens the association of alpha 3 beta 1 integrin with the tetraspanin-enriched microdomains and affects integrin-dependent signaling. J. Biol. Chem. 2002, 277, 36991-37000. [CrossRef]

117. Schröder, J.; Lüllmann-Rauch, R.; Himmerkus, N.; Pleines, I.; Nieswandt, B.; Orinska, Z.; Koch-Nolte, F.; Schröder, B.; Bleich, M.; Saftig, P. Deficiency of the tetraspanin CD63 associated with kidney pathology but normal lysosomal function. Mol. Cell. Biol. 2009, 29, 1083-1094. [CrossRef]

118. Goschnick, M.W.; Lau, L.M.; Wee, J.L.; Liu, Y.S.; Hogarth, P.M.; Robb, L.M.; Hickey, M.J.; Wright, M.D.; Jackson, D.E. Impaired “outside-in” integrin alphaIlbbeta3 signaling and thrombus stability in TSSC6-deficient mice. Blood 2006, 108, 1911-1918. [CrossRef]

119. Uchtmann, K.; Park, E.R.; Bergsma, A.; Segula, J.; Edick, M.J.; Miranti, C.K. Homozygous loss of mouse tetraspanin CD82 enhances integrin $\alpha \mathrm{Ilb} \beta 3$ expression and clot retraction in platelets. Exp. Cell Res. 2015, 339, 261-269. [CrossRef]

120. Lang, F.; Münzer, P.; Gawaz, M.; Borst, O. Regulation of STIM1/Orai1-dependent $\mathrm{Ca}^{2+}$ signalling in platelets. Thromb. Haemost. 2013, 110, 925-930.

121. Gavin, R.L.; Koo, C.Z.; Tomlinson, M.G. Tspan18 is a novel regulator of thrombo-inflammation. Med. Microbiol. Immunol. 2020. [CrossRef] [PubMed]

122. Hong, C.; Choi, S.H.; Kwak, M.; Jeong, B.; Ko, J.; Park, H.J.; Choi, S.; Jun, J.Y.; So, I. TRPC5 channel instability induced by depalmitoylation protects striatal neurons against oxidative stress in Huntington's disease. Biochim. Biophys. Acta Mol. Cell Res. 2020, 1867, 118620. [CrossRef] [PubMed]

(C) 2020 by the authors. Licensee MDPI, Basel, Switzerland. This article is an open access article distributed under the terms and conditions of the Creative Commons Attribution (CC BY) license (http://creativecommons.org/licenses/by/4.0/). 